\title{
The Volume of Issuance of Government Islamic Securities SR-007 Series, 2015-2018
}

\author{
Rima Ayu Shintyawati ${ }^{1}$, Caturida Meiwanto Doktoralina ${ }^{1}$, Nurhasanah $^{1} \&$ Sri Anah $^{1}$ \\ ${ }^{1}$ Faculty of Economics and Business, Universitas Mercu Buana, Jakarta, Indonesia \\ Correspondence: Caturida Meiwanto Doktoralina, Faculty of Economics and Business, Universitas Mercu Buana, \\ Jakarta, Indonesia. E-mail: caturida_meiwanto_drm@mercubuana.ac.id
}

Received: October 13, 2019

Accepted: January 1, 2020

Online Published: September 21, 2020

doi:10.5430/ijfr.v11n5p56

URL: https://doi.org/10.5430/ijfr.v11n5p56

\begin{abstract}
In Islamic finance, Sukuk instruments are similar to the bond market in conventional finance and are intended to increase long-term investment capital. However, according to Sharia, Sukuk means there is no uncertainty (Garar), interest (usury) and gambling (Maisir).This is also new in the financial market in Islamic Bank. The government uses Sukuk as an instrument for financing the state budget, and Sukuk financing has contributed to the development and financing of state projects. The amount of Sukuk issuance volume is influenced by external factors such as macroeconomic conditions and internal factors, namely prices and yields of Sukuk. The problem is whether inflation, exchange rates, Sukuk prices and returns affect the volume of Sukuk issuance. Therefore, this research aims to determine the effect of macroeconomic variables (inflation and exchange rates), Sukuk prices and Sukuk yields on the volume of Retail Sukuk issuance in Indonesia, using the Vector Error Correction Model (VECM) research model and the assistance of econometrics EViews 9. The data used in this study are time-series data from April 2015 to March 2018, with a research sample of Retail Sukuk with the latest maturity in March 2018, namely Retail Sukuk SR-007 series. The results of the study show that the inflation and price variables have a long-term significant influence on the volume of Retail Sukuk SR-007 issuance and only yield variables that do not influence both the long- and short-term, while the exchange rate variable has significant long- and short-term effects.
\end{abstract}

Keywords: issuance volume, retail Sukuk, inflation, exchange rate, Sukuk prices, yield, VECM

\section{Introduction}

Since the World Bank (2008) stated that Islamic finance has grown exponentially and outperformed conventional financial instruments, many varieties of Sukuk have been offered in Indonesia. This issue of that Islamic finance has grown was later linked to the number of Indonesian Muslims, totalling 231 million but not yet growing rapidly (Pew Research, 2018). The Government of Indonesia used State Government Islamic Securities (SBN) to support innovation and development of the Islamic finance industry, with a positive impact on infrastructure development of USD 16.15 million (Direktorat Jenderal Pengelolaan Pembiayaan dan Risiko Kementerian Keuangan, 2018; Sumaidi, 2018). The increase in outstanding 44 types of Sukuk amounted to Rp 615.39 trillion (an increase of 20\%) compared to the outstanding 37 Sukuk in 2017 (Rp 512.33 trillion), indicating positive Sukuk growth that helped finance the State Budget (APBN) deficit and could be used as an instrument for financing project development (Kementerian Keuangan, 2018; Khatimah, 2017).

One of the impacts of government regulation is that the development of Islamic finance has reached a market share of $8.47 \%$ of Indonesia's total financial assets (Otoritas Jasa Keuangan, 2018). The contributions of the Islamic capital market beyond the capitalization of shares listed in the Indonesian Syariah Stock Index (ISSI) is equal to 54.94\%, or Rp 661.71 trillion. That is why the effect on the price and volume of Sukuk shares issued by the capital market is quite promising (Cheung, Cheung, He, \& Wan, 2010). Therefore, the issue of the independent variable of this research discusses the increasing volume of Retail Sukuk issuance (SR) - where SR is a type of Sukuk issued by the state that can be purchased by any Indonesian citizen through a selling agent - that has a value of Rp 2.64 trillion $(14 \%)$, where the yield given is $0.5 \%$ smaller and the number of investors is less than that of the SR-006.

The factual development of retail Sukuk in Indonesia is inseparable from the characteristics of the investment product itself, such as the price of the Sukuk and the level of yield provided and general economic conditions. Many macroeconomic indicators can influence the development of retail Sukuk in Indonesia. Those indicators such as 
inflation, income (per capita) and the Rupiah exchange rate against foreign currencies and interest rate (Apriliani, Azib, \& Senjiat, 2017). In this case, the authors focus on the variable inflation rate and exchange rate. The inflation rate is an important concern for a stable economic environment for the development of bond and Sukuk markets. High inflation can cause a lack of investor interest (Hansen, 2016; Kuncoro, 2013). The exchange rate was selected because SBSN uses IDR and \$ USD transactions, which affect investors' investment decisions. The reason investors consider logical investments is because they have an interest in obtaining long-term benefits for the investments made.

Pricing for securities requires a compelling and credible rate, so investors and publishers must regularly distribute Sukuk with different maturities to create a yield curve (Zulkhibri, 2015). The issuance volume of Sukuk bonds is related to market risk, which includes interest, risk of inflation and exchange rates. Therefore, investors maintain the Sukuk value until the maturity period, without numerous fluctuations that require the support of return analysis (Kamarudin, Kamaluddin, Manan, \& Ghani, 2014) because the fluctuating volume of Sukuk issuance can be caused by economic variable shocks (N. Ahmad, Hashim, \& Johari, 2015). Some studies on the reaction of the bond market and the stock market show that the transition in the volume of stock issuance affects the decline in bond prices (Abaffy, Bertocchi, Dupačová, Moriggia, \& Consigli, 2007). The negative reaction to bond prices also decreases the price of stock market issues (Abad-Romero \& Robles-Fernandez, 2006; Jorion \& Zhang, 2007). In macroeconomics, inflation is decisive as a market factor, and the volume of issuance is one of the references for investors to invest (Adam \& Thomas, 2004; Mohamed Ariff, Iqbal, \& Mohamad, 2012). This is also supported by Said \& Grassa (2013); Soekapdjo, Nugroho, Badawi, \& Utami (2018); and Tim Studi Minat Emiten di Pasar Modal (2009), who state that external factors (such as macroeconomics) are influential because they are difficult to predict and control.

Inflation is an important concern for a stable economic environment for the development of the bond and Sukuk markets. The high value of inflation can cause a lack of investor interest (Hansen, 2016; Kuncoro, 2013). Research by Said \& Grassa (2013) found a significant negative effect on the development of the Sukuk market for inflation, which caused a financial crisis due to a decrease in the number of outstanding Sukuk bonds. Therefore, F. Rahman, Paminto, \& Nardi, 2016; Yanti, 2016 found that a low inflation rate can provide a positive signal of increased purchasing power towards trade and investment in bonds. Therefore, the Sukuk SR-007 volume by the Indonesian Government continues. In reality, the inflation theory is not suitable for the phenomenon that shows a downward trend in the volume of Sukuk SR-007 issuance when the inflation rate is low. This can be proven in November 2017, the inflation rate was 3.3\% but the volume of Sukuk SR-007 issuance was only Rp 796 billion while in December 2017 inflation was $3.61 \%$ and was able to reach the issuance volume of Rp 1.804 billion.

Exchange rates are important for monetary policy authorities in achieving price stability. The interest of policy authorities is because the exchange rate has a significant influence on the issuance of Sukuk in the capital market (W. Ahmad \& Radzi, 2011). In addition, the exchange rate in Indonesia is not always stable. The exchange rate of the Rupiah (IDR) against the US dollar (USD) has an indirect relationship through investor behaviour (Malkiel, 2015).

Meanwhile, SBSN uses IDR and \$ USD transactions, which affects investors' investment decisions. The reason investors consider investment logical is because they have an interest in obtaining long-term benefits for investments made. If \$ USD is valued, investors will switch from Sukuk to other investments using foreign exchanges and conversely if \$ USD depreciates, investors tend to choose to invest in Retail Sukuk given the certainty of low yield and risk levels. Therefore, the exchange rate is important as one of the macroeconomic factors that also affects the volume of Sukuk issuance (Arshad, Muda, \& Osman, 2018; Manab \& Sujianto, 2016; Suriani, Majid, Masbar, \& Wahid, 2018)

In demand theory, a product is influenced by prices inherent in the product and in terms of investment (Hildenbrand, 2014). If the price of Sukuk is high, the demand for Sukuk will be low, whereas a low Sukuk price will increase demand for Sukuk (Wafa, 2010). Thus, Sukuk offers still fluctuate. Additionally, a low Sukuk price should increase the volume of Sukuk issuance, but the theory is not in accordance with this phenomenon. Where the volume of Sukuk issuance in September 2015 decreased by Rp 8.6 trillion (96\%) compared in August 2015 i.e., Rp 10.87 trillion (99.25\%). This negative influence is also supported by Rahman et al. (2016), which states that prices have a negative effect and are not significant to the demand for Sukuk SR-005 countries. Because there are differences between the theories and phenomena that occur, this research related to Sukuk needs to be reviewed.

The Sukuk yield has the potential for capital gains if there is a tendency for price increases in the secondary market (Huda \& Heykal, 2010). This specialty of Sukuk has caused the volume of Sukuk issuance SR 001-SR 010 to grow with yield between 5.90\%-12\% (Direktur Jenderal Pengelolaan Utang, 2009). Other strong factors that influence investors' investing decisions are yields as payments that can take the form of profit/margin/fee or other forms of 
payment in accordance with Sukuk emission agreements granted to Sukuk holders until the end of the Sukuk period (M Ariff, Chazi, Safari, \& Zarei, 2017; Melzatia, Doktoralina, \& Mahroji, 2018; Sholihin, 2010). The yield rate shows that the Retail Sukuk SR-007 was highest in January 2018 (10.12\%), while the lowest yield was in March 2017 (5.97\%). Thus, yields stably fluctuate and tend to increase. This is to support research conducted by Mohamed Ariff et al., 2012; Fathurahman \& Fitriati, 2013; Naifar, 2016, who found that yields had a positive influence on Sukuk issuance. However, research conducted by Marimin, Mustofa, \& Anik (2016) states that there are no differences in the performance of Sukuk and Islamic bonds if measured from each yield. There is an inconsistency in this phenomenon, which is a gap and establishes the need for further research.

Price theory states that prices are closely related to the allocation of resources between different uses or the price of one item relative to other goods (Friedman, 2017). Signalling theory states that information must have relevance that can be utilized by the recipient to be adjusted by the recipient based on the behaviour of the signal (Spence, 1973). Based on the Sukuk Issue, gap and previous research, the title of The Volume of Issuance of Government Islamic Securities SR-007 Series, 2015-2018, we did. The first problem is whether inflation affects the volume of Retail Sukuk issuance. Second, does the exchange rate affect the volume of Retail Sukuk issuance? Third, does the Sukuk price affect the volume of Retail Sukuk issuance? Last, regarding Sukuk issuance, does the Sukuk yield affect the volume of Retail Sukuk issuance?

\section{Literature Review}

\subsection{Theoretical Study}

There are four theories on the relevance of research in Sukuk issuance: price theory (Friedman, 2017), demand theory (Hildenbrand, 2014), trading volume theory (Karpoff, 1986) and signalling theory (Spence, 1973). However, market participants need information for interpreting and analysing information as good or bad news (Hartono, 2016). One of information as good or bad news is Sukuk volume which has the potential to obtain capital gains and low risk because the state guarantees $100 \%$ of income payments and a high return of $12 \%$ gross $=>9.6 \%$ net compared to other conservative products, such as money market funds or deposits (Abidin, Suhadak, \& Hidayat, 2016; Suharto, 2015). In this research, the usual theory used is the grand theory used is signalling theory.

\subsection{Sukuk (Sharia Bonds)}

The fatwa of the National Sharia Board (DSN) explains that Islamic bonds (including Sukuk) are long-term securities based on Sharia principles in Indonesia (Nurhayati \& Wasilah, 2014). Sukuk is distinguished according to the contract, Sukuk Mudharabah (sukuk based on equity partnership), Sukuk musyarakah (joint venture sukuk), Sukuk Istisna (Islamic project bond), Sukuk Ijarah (lease-based sukuk).

The structure of Sukuk is based on tangible assets, namely the value of Sukuk, which pool of assets can comprise of Murabahah, Ijarah as well as Istisna'a. Therefore, investment income is not based on interest rates but rather rewards and margin/profit-sharing ratios according to what is accrued. Nurhayati \& Wasilah (2014) stated that the characteristics of Islamic Sukuk have the same involvement in gains and losses through fixed-asset assets, outstanding assets or maknawiyah rights. The purpose of circulating assets is mandatory through the mediation of the syar'i system, where they can be traded, can be rated, can be added to, have legal flexibility with different tax treatments, and can be redeemed based on a transaction or underlying Islamic contract (Widyanto, 2018).

\subsection{Retail Sukuk}

SR is a Sharia investment product issued by the government and sold to individual Indonesian Citizens (WNI) through a sales agent. There are still three investment risks with Retail Sukuk: risk of default failure, liquidity risk and market risk. However, the advantages for investors who buy Retail Sukuk are a fixed fee every month, the potential for capital gains due to a selling price of Retail Sukuk that is higher than the purchase price, and government-guaranteed investments (low risk). In addition, returns on Sukuk are relatively high at $12 \%$ gross $\Rightarrow$ 9.6\% net compared to other conservative products, such as money market funds or deposits (Huda \& Heykal, 2013; Kementerian Keuangan, 2018). Retail Sukuk investment is, in principle, an investment that is free from the risk of default, namely the failure of the government to pay compensation, and of nominal value to investors.

\subsection{Effect of Inflation on Issuance Volume}

According to Alagidede \& Ibrahim, (2017); Oikawa \& Ueda, (2018); Sukirno, (2015) the inflation rate will affect a country's economic development. High inflation will not promote economic development. When inflation is high, capital owners prefer to use their money to buy fixed assets such as land, houses, and buildings. This is because of the large profit level when the goods are resold. Unstable inflation will create uncertainty for economic actors in 
making decisions. Empirical experience shows that unstable inflation will complicate people's decisions in consumption, investment and production, which in turn will reduce economic growth (Bank Indonesia, 2018; Keynes, 2018). This condition will have an impact on investment demand in the capital market including Sukuk because few people save their funds in the capital market. Based on this, then $\mathrm{H}_{1}$ : Inflation affects the volume of Retail Sukuk SR-007 issuance.

\subsection{Effect of Exchange Rate on Issuance Volume}

Exchange rates are used as a measure of prices in international transactions (De Grauwe \& Grimaldi, 2018; Mankiw, Quah, \& Wilson, 2014; Sukirno, 2015). Determination of a fixed exchange rate is based on the exchange rate system - which sets the value of the foreign exchange rate against the currency of the country concerned with a certain value that does not change in a certain period - Second, Floating Exchange Rate (FER) is the determination of the value of a country's currency determined bythe power of demand and supply on official and Third money markets, namely the Pegged Exchange Rate - PER, which is to associate value exchange with the value of another country's currency (Putong, 2013). Unstable fluctuations in the foreign exchange rate automatically affect trading increases and decreases in bonds (Rahardjo, 2003). Based on this, then $\mathrm{H}_{2}$ : Exchange rates affect the volume of Retail Sukuk issuance.

\subsection{Effect of Sukuk Prices on Issuance Volume}

Price is one of the factors that can influence the demand for goods and services, including the demand for Sukuk. Essentially the lower the price of an item, the more demand will be for that item. Conversely, the higher the price of an item, the less demand for that item (Sukirno, 2012). In demand theory, what changes the balance along the retail Sukuk demand curve is the interest rate and retail Sukuk prices. In Addition, the investor tends to obtain for buying Indonesian Retail Government Bonds (ORI) compared to retail Sukuk because they have a fixed return with high prices (F. Rahman et al., 2016). Based on research conducted by (Sadeghi, 2015; Wafa, 2010) the price of Sukuk has a significant effect on the volume of retail Sukuk issuance.Based on this, then $\mathrm{H}_{3}$ : Sukuk prices affect the volume of Retail Sukuk SR-007 issuance.

\subsection{Effect of Yield on Issuance Volume}

Sukuk retail is one investment instrument, so basically, an investor would want a high profit as a result of the purchase of this Sukuk. Before deciding to invest, investors consider the amount of Sukuk yield as one of the factors measuring the rate of return to be received. The amount of yield can affect investor demand to buy Sukuk. In general, investors will buy Sukuk if the rate of return provided is higher because it is considered to provide promising benefits. This is in line with research Mohamed Ariff \& Safari, 2012; Fathurahman \& Fitriati, 2013; Naifar, 2016 that the yield has a positive effect on the volume of retail Sukuk issuance. Based on this, then $\mathrm{H}_{4}$ : Yield affects the volume of Retail Sukuk issuance

For the entire hypothesis, the theoretical model is (Figure 1):

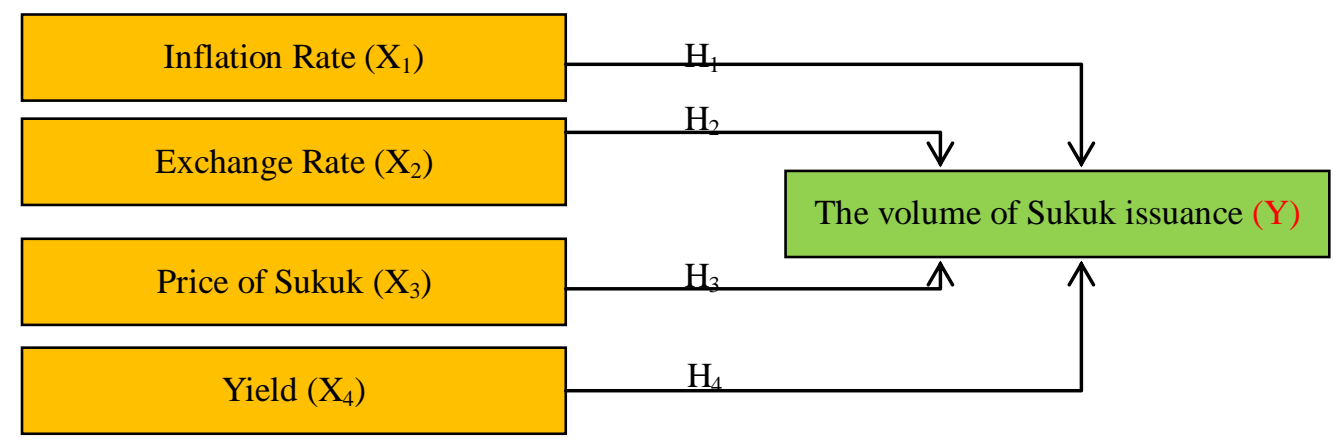

Figure 1. Research model

\section{Research Methods}

The analytical methods used were the Vector Autoregression (VAR) method or the Vector Error Correction Model (VECM) method if occurs cointegration between a variable with the help of EViews 9 (Widarjono, 2013). The approach of all variables is considered endogenous, and estimation can be carried out simultaneously or sequentially 
(Ariefianto, 2012).

\subsection{Research Design}

This study was a type of causal research. The aim was to test the hypothesis about the effect of one or several independent variables on the dependent variable (Agung, 2011; Hox, Moerbeek, \& de Schoot, 2017; Ouliaris, Pagan, \& Restrepo, 2016; Wati, 2018). The dependent variable (Y) is Retail Sukuk SR-007 Issuance Volume and the independent variables are inflation $\left(\mathrm{X}_{1}\right)$, exchange rate $\left(\mathrm{X}_{2}\right)$, Sukuk prices $\left(\mathrm{X}_{3}\right)$ and Sukuk yield payments $\left(\mathrm{X}_{4}\right)$.

\subsection{Operational Definition of Variables}

Retail Sukuk SR-007 issuance volume is an important indicator of trade market analysis. The volume shows the number of transactions traded on the market in a certain period and can illustrate the strength between selling and buying an interest in market transactions, such as the number of issuers' shares (Abidin et al., 2016; Suharto, 2015). Inflation is the tendency of increasing prices of goods and services in general and continuously (Galí, J., 2015; Kuncoro, 2013) and is measured through the Consumer Price Index (CPI) obtained from the official website of Bank Indonesia.

Exchange rate (exchange rate) is the rupiah exchange rate (IDR) against the US dollar (USD), referring to the official website of Bank Indonesia. Exchange rates are important for businesspeople and related to business planning because changes can cause risks in bond market trading (Noor, 2009; Rahardjo, 2003). Meanwhile, bond prices are expressed as a percentage (\%), which is the percentage of the nominal value and yield expressed as a percentage of the total income received by investors from investment in Sukuk securities (Fahmi, 2012; Sitorus, 2015).

\subsection{Population and Sample}

The population in this research was Retail Sukuk issued by the government from 2015 to 2018. Nonprobability sampling techniques were used to support research (Wati, 2018) of the 36 Retail Sukuk SR-007 monthly secondary data was due from March 2018 from the Indonesia Stock Exchange and Bank Indonesia. Technically, the data was collected using library techniques, and Secondary data was obtained from Indonesia Stock Exchange (IDX) and Bank Central of Indonesia (BI) with time-series data during the period April 2015-March 2018. They note the effect of inflation, exchange rates, prices and yields on the volume of Retail Sukuk issuance. Based on the conceptual research framework, transformation is carried out to produce linear information using natural logarithms $(\mathrm{Ln})$ through the following equation.

$$
\text { VOL }=\beta_{0}+\beta_{1} \text { Inflation }_{t t}+\beta_{2} \text { Ln Exchange Rate }_{\text {st }}+\beta_{3} \text { Price }_{\mathrm{t}}+\beta_{4} \text { Yield }_{\mathrm{t}}+\mu_{\mathrm{t}}
$$

Information:

$\begin{array}{ll}\text { Ln } & : \text { Linear Logarithm } \\ \text { Vol. } & : \text { Retail Sukuk SR-007 issuance volume } \\ \text { Inflation } & : \text { Inflation Rate (percentage) } \\ \text { Exchange rate } & : \text { The exchange rate of the rupiah against the US dollar } \\ \text { Price } & : \text { Price of Retail Sukuk SR-007 (percentage) } \\ \text { Yield } & \text { : Yield of Retail Sukuk SR-007 (percentage) } \\ \mathrm{M} & : \text { Margin error } \\ \mathrm{T} & : \text { Time series } \\ \beta_{0} & : \text { Intercept } \\ \beta_{1}, \beta_{2}, \beta_{3}, \beta_{4} & : \text { Regression coefficient }\end{array}$

\section{Results and Discussion}

\subsection{Variable Stationary Test}

This stationarity test was carried out with Augmented Dicky-Fuller (ADF) with a real level of 5\%. If the ADF statistical value is more significant than Mackinnon's critical value (5\%), then the data is stationary because it does not contain the unit root. Conversely, if the ADF test results are smaller than the critical value, then the data is not stationary and must be tested at the first-difference level (Hill, Griffiths, \& Lim, 2018; Maiti, 2017; Thierry, Jun, Eric, Yannick, \& Landry, 2016). Table 1 shows that three variables - exchange rate, yield and volume - are stationary, while inflation and price variables are not stationary; thus, the ADF test must be done at first-difference. 
Table 1. Stationary Test

Augmented Dickey-Fuller Data Level

\begin{tabular}{|c|c|c|c|c|c|c|}
\hline \multirow{2}{*}{ Variable } & \multirow{2}{*}{$\begin{array}{c}\text { ADF } \\
\text { t-statistic }\end{array}$} & \multicolumn{3}{|c|}{ Critical Value } & \multirow[t]{2}{*}{ Prob } & \multirow[t]{2}{*}{ Result } \\
\hline & & $1 \%$ & $5 \%$ & $10 \%$ & & \\
\hline Inflation & -1.798051 & -3.632900 & -2.948404 & -2.612874 & 0.375300 & Not stationary \\
\hline Exchange Rate & -3.208594 & -3.632900 & -2.948404 & -2.612874 & 0.027900 & Stationary \\
\hline Price & -2.911372 & -3.632900 & -2.948404 & -2.612874 & 0.054200 & Not stationary \\
\hline Yield & -4.782935 & -3.632900 & -2.948404 & -2.612874 & 0.000500 & Stationary \\
\hline Volume & -3.481368 & -3.632900 & -2.948404 & -2.612874 & 0.014600 & Stationary \\
\hline \multicolumn{7}{|c|}{ Augmented Dickey-Fuller First-Difference } \\
\hline \multirow{2}{*}{ Variable } & \multirow{2}{*}{$\begin{array}{c}\text { ADF } \\
\text { t-statistic }\end{array}$} & $\begin{array}{l}\text { Critical } \\
\text { Value }\end{array}$ & Prob & Hasil & \multirow{2}{*}{ Variable } & \multirow{2}{*}{$\begin{array}{c}\text { ADF } \\
\text { t-statistic }\end{array}$} \\
\hline & & $1 \%$ & $5 \%$ & $10 \%$ & & \\
\hline Inflation & -5.475240 & -3.639407 & -2.951125 & -2.614300 & 0.000100 & Stationary \\
\hline Price & -7.566561 & -3.639407 & -2.951125 & -2.614300 & 0.000000 & Stationary \\
\hline
\end{tabular}

Source: Data Processed (2019)

The ADF test results on the first-difference show the stationary inflation and price variables as evidenced by the ADF t-statistic value in the inflation variable, which is $-5.475240>0.05$ and the ADF t-statistic value for the price variable which is $-7.566561>0.05$. From the results of the ADF test, it was concluded that all data was stationary, and it could be used for research at a later stage.

\subsubsection{Optimum Lag Test and VAR Stability Test}

The Optimum Lag Test overcame the problem of autocorrelation in the VAR system through the of Final Prediction Error Correction (FPE) criteria or the smallest number of AIC, SIC and HQ among the various lags proposed or paying attention the number of asterisks $(*)$ in the lags (Ajija, Wulansari, Setianto, and Primanti, 2011). Noting Table 2, the smallest number of AIC, SIC and HQ and the most significant number of asterisks $(*)$ which is located in the one with the smallest AIC value of -13.49598. The next process is to ensure that the optimum lag chosen is stable against the VAR, so the VAR stability test must done by looking at the modulus value of each unit root below 1. From the results of the VAR stability test (Table 3), it is known that the entire modulus at the root of the unit is less than 1, so the VAR equation was stable.

Table 2. Optimum Lag Test

\begin{tabular}{ccrrrrr}
\hline Lag & LogL & \multicolumn{1}{c}{ LR } & FPE & AIC & SC & HQ \\
\hline 0 & 2.010 .605 & NA & $6.74 \mathrm{e}-12$ & -1.153 .297 & -1.130 .851 & -1.145 .642 \\
\hline 1 & 2.594 .317 & $96.14084^{*}$ & $9.65 \mathrm{e}-13^{*}$ & $-13.49598^{*}$ & $-12.14920^{*}$ & $-13.03669^{*}$ \\
\hline 2 & 2.802 .838 & 2.821 .166 & $1.36 \mathrm{e}-12$ & -1.325 .199 & -1.078 .288 & -1.240 .995 \\
\hline
\end{tabular}

Source: Data Processed (2019)

Table 3. VAR Stability Test Results

\begin{tabular}{cl}
\hline Root & Modulus \\
\hline 0.765549 & 0.765549 \\
0.612201 & 0.612201 \\
0.423615 & 0.423615 \\
-0.290224 & 0.290224 \\
0.099360 & 0.099360 \\
\hline
\end{tabular}

Source: Data Processed (2019) 


\subsubsection{Cointegration Test}

Cointegration tests are used to determine the existence of long-term relationships between variables in the VAR system. This study used the Johansen cointegration test model. In the test, as in Table 4, If trace statistics> critical values, it can be concluded that the variables used have cointegration so that the analysis used is VECM. In the test, as in Table 4, the Unrestricted Cointegration Rank Test (Trace) that the value of None * trace statistic is 98.09362> critical value 69.81889. Additionally, the output of the Unrestricted Cointegration Rank Test (maximum eigenvalue) showed the max eigenvalue stat value of $38.63972>$ critical value 33.87687 , and the probability is smaller than $5 \%$.

Table 4. Cointegration Test results

Unrestricted Cointegration Rank Test (Trace)

\begin{tabular}{|c|c|c|c|c|}
\hline Hypothesized & & Trace & 0.05 & \\
\hline No. of CE(s) & Eigenvalue & Statistic & Critical Value & Prob.** \\
\hline None * & 0.679048 & 98.09362 & 69.81889 & 0.0001 \\
\hline At most $1 *$ & 0.533457 & 59.45390 & 47.85613 & 0.0028 \\
\hline At most $2 *$ & 0.410158 & 33.53215 & 29.79707 & 0.0177 \\
\hline At most $3 *$ & 0.234713 & 15.58353 & 15.49471 & 0.0485 \\
\hline At most $4 *$ & 0.173731 & 6.488385 & 3.841466 & 0.0109 \\
\hline
\end{tabular}

Trace test indicates 5 cointegrating eqn(s) at the 0.05 level; * denotes rejection of the hypothesis at the 0.05 level; **MacKinnon-Haug-Michelis (1999) p-values

Unrestricted Cointegration Rank Test (Maximum Eigenvalue)

\begin{tabular}{|c|c|c|c|c|}
\hline \multirow{2}{*}{$\begin{array}{l}\text { Hypothesized } \\
\text { No. of CE(s) }\end{array}$} & \multirow[b]{2}{*}{ Eigenvalue } & \multirow{2}{*}{$\begin{array}{l}\text { Max-Eigen } \\
\text { Statistic }\end{array}$} & \multicolumn{2}{|l|}{0.05} \\
\hline & & & Critical Value & Prob.** \\
\hline None* & 0.679048 & 38.63972 & 33.87687 & 0.0125 \\
\hline At most 1 & 0.533457 & 25.92175 & 27.58434 & 0.0803 \\
\hline At most 2 & 0.410158 & 17.94862 & 21.13162 & 0.1318 \\
\hline At most 3 & 0.234713 & 9.095141 & 14.26460 & 0.2783 \\
\hline At most $4 *$ & 0.173731 & 6.488385 & 3.841466 & 0.0109 \\
\hline
\end{tabular}

Source: Data Processed (2019)

Based on the econometric analysis, among the five variables in this study, there was one cointegration at the 5\% significance level. Thus, the results of the cointegration test indicated that between the movements of inflation, exchange rates, prices and yields have a long-term relationship of stability/balance and similarity of movements so the method used in this study was the Vector Error Correction Model (VECM).

\subsubsection{Vector Error Correction Model (VECM)}

VECM is used to calculate long-term and short-term relationships between variables. The trick is to look at the comparison of t-statistic values resulting from the estimation of the t-label value. If the t-statistic value is greater than the t-table value, then the results can be said to have a long- or short-term relationship between variable (Ajija et al., 2011).

From Table 5, it is known that the t-table value is 1.69552. Based on the testing, the long-term t-statistic value is $-5.25689<1.69552$ and short-term t-statistic value is $-2.13404<1.69552$. Then statistically the short- and long-term outcome variables do not affect the issuance volume variable, whereas the exchange rate variable has an influence on the volume of Retail Sukuk issuance both in the long- and short-term. The variable long-term exchange rate has a positive effect on the volume of issuance with a t-statistic value of $6.18 \%$, which means that if the exchange rate rises by $1 \%$, there will be an increase in the volume of issuance of $6.18 \%$. 
Table 5. Vector Error Correction Model Test results

\begin{tabular}{lccc}
\hline \multicolumn{2}{c}{ Long-Term } & \multicolumn{2}{c}{ Short-Term } \\
\hline Cointegrating & CointEq1 & Error Correction & \multicolumn{1}{c}{ CointEq1 } \\
\hline Vol & & D Vol & -1.440536 \\
& & & $(0.28372)$ \\
& & & {$[-5.07733]$} \\
\hline VOL(-1) & & D(VOL(-1)) & 0.621079 \\
& & & $0.21665)$ \\
& & & {$[2.86667]$} \\
\hline EXR(-1) & 40.60647 & D(EXR(-1)) & 31.45105 \\
& $(6.56345)$ & & $(9.07605)$ \\
& {$[6.18676]$} & & {$[3.46528]$} \\
\hline INF(-1) & 0.577333 & D(INF(-1)) & 0.554968 \\
& $(0.28628)$ & & $(1.04783)$ \\
& {$[2.01666]$} & & {$[0.52964]$} \\
\hline PRICE(-1) & 39.54118 & D(PRICE(-1)) & 7.250576 \\
& $(16.9657)$ & & $(19.5864)$ \\
& {$[2.33066]$} & & {$[0.37018]$} \\
\hline YIELD(-1) & -3.433 .230 & $\mathrm{D}($ YIELD(-1)) & -2.623 .305 \\
& $(0.65309)$ & & $(1.22927)$ \\
& {$[-5.25689]$} & & {$[-2.13404]$} \\
\hline @ TREND(15M04) & 0.058497 & $\mathrm{C}$ & -0.089472 \\
& $(0.00583)$ & & $(0.10588)$ \\
& {$[10.0411]$} & & {$[-0.84502]$} \\
\hline
\end{tabular}

Source: Data Processed (2019)

Inflation and Sukuk prices also play a role in increasing the volume of issuance in the long-term with t-statistic $2.01 \%$ and $2.33 \%$, which means there will be an increase in Sukuk issuance volume of $2.01 \%$ and $2.33 \%$, if inflation and Sukuk prices increase by $1 \%$. It can be concluded that the exchange rate variable has a long- and short-term effect on the volume of Retail and Variable Sukuk issuance. Sukuk inflation and prices have a long-term effect on the volume of Retail Sukuk issuance. The yield variable does not affect the volume of Retail Sukuk issuance

\subsubsection{Granger Causality Test}

Granger causality tests are used to determine the causal relationship between endogenous variables by comparing a critical value $(\mathrm{CR})$ with variable probability. The result is the significant value used is $5 \%$. The variable exchange rate, inflation, Sukuk price and yield do not have a causal relationship with Sukuk issuance volume because all the probability values are $>5 \%$, while the variables that occur causally are exchange rates with Sukuk prices and yields with probability values 0.0327 and 0.0422 . In addition to these two variables, the variable inflation with Sukuk prices causes a causal relationship with a probability value of 0.0222 .

\subsubsection{Impulse Response Function (IRF) Test and Variance Decomposition (FEVD) Test}

The IRF test results (Table 6) show that the response of the issuance volume to the exchange rate and price variables had a negative and fluctuating response from the 1st to the 10th period. Positive volume issuance responses occur in inflation and yield variables. In the first period, the response of the issuance volume to inflation shocks was a positive response of $0.07 \%$ and fluctuated stably in the $8^{\text {th }}-10^{\text {th }}$ periods, with a response range of $0.05 \%$. Furthermore, the positive response of the issuance volume to the yield variable in the first period was $0.25 \%$ and increased in the second period to $0.47 \%$. However, there was a decline in the response in the 4 th and 5 th periods, which subsequently increased in the 6th to 10th period. The positive response of issuance volume to yield shocks fluctuated stably with a response of $0.31 \%$ at the end of the $10^{\text {th }}$ period.

The FEDV test results (Table 6) show that the price variable had the most significant contribution to the issuance 
volume fluctuations among the other three independent variables. The increase evidences this, since the first period of $23.44 \%$ continued to increase until the $10^{\text {th }}$ period, with a contribution of $31.23 \%$. In line with the price variable, the contribution that continued to increase was also shown by the yield variable with a contribution of $7.2 \%$ in the first period and an increase of $166 \%$ in the second period to $19.22 \%$, continuing to increase until the final period of $22.04 \%$. Furthermore, the exchange rate and inflation variables showed the highest contribution among all periods that occurred in the third period of $3.16 \%$ and $1.14 \%$, respectively, but continued to decline in contributions to $2.46 \%$ and $0.87 \%$ in the final period.

Table 6. IRF and FEDV Test

\begin{tabular}{cccccc|cccccc}
\hline \multicolumn{7}{c|}{ Result of IRF Test } & \multicolumn{5}{c}{ Result of FEDV Test } \\
\hline Period & VOL & EXR & INF & PRICE & YIELD & S.E. & VOL & EXR & INF & PRICE & YIELD \\
\hline 1 & 0.601217 & 0.000000 & 0.000000 & 0.000000 & 0.000000 & 0.601217 & 100.0000 & 0.000000 & 0.000000 & 0.000000 & 0.000000 \\
2 & 0.502611 & -0.11845 & 0.073907 & -0.4628 & 0.256478 & 0.955790 & 67.22015 & 1.535777 & 0.597923 & 23.44546 & 7.200690 \\
3 & 0.342645 & -0.18585 & 0.109939 & -0.47624 & 0.478568 & 1.238307 & 47.70337 & 3.167492 & 1.144431 & 28.75896 & 19.22575 \\
4 & 0.392277 & -0.02919 & 0.037034 & -0.31106 & 0.276872 & 1.364890 & 47.52562 & 2.652961 & 1.015624 & 28.86582 & 19.93997 \\
5 & 0.432394 & -0.0929 & 0.047136 & -0.35027 & 0.286501 & 1.505163 & 47.33276 & 2.562484 & 0.933213 & 29.15183 & 20.01971 \\
6 & 0.406836 & -0.11998 & 0.062920 & -0.40524 & 0.334306 & 1.650867 & 45.41952 & 2.658317 & 0.921016 & 30.25858 & 20.74256 \\
7 & 0.397269 & -0.08839 & 0.060391 & -0.36211 & 0.321390 & 1.768915 & 44.60343 & 2.565039 & 0.918743 & 30.54531 & 21.36747 \\
8 & 0.413506 & -0.08876 & 0.052378 & -0.36113 & 0.304872 & 1.879902 & 44.33057 & 2.494011 & 0.891093 & 30.73532 & 21.54901 \\
9 & 0.409423 & -0.10142 & 0.057753 & -0.3774 & 0.318109 & 1.989698 & 43.80720 & 2.486184 & 0.879710 & 31.03444 & 21.79247 \\
10 & 0.405139 & -0.09628 & 0.058201 & -0.37181 & 0.318887 & 2.091800 & 43.38624 & 2.461235 & 0.873341 & 31.23822 & 22.04097 \\
\hline
\end{tabular}

Source: Data Processed (2019)

\subsection{Discussion}

Based on the results of the tests that have been executed, inflation has a significant long-term effect on the volume of Retail Sukuk SR-007 issuance, which can be seen from the VECM test results t-statistics with t-table in the long run of $2.01666>1.69552$. In the long run, when inflation rises, the country needs more capital to stabilise the country's economy, as well as the country issues Sukuk to get investment from the public. The results of this study support M. P. Rahman et al., (2017) who stated that the inflation rate affects the yields of state Sukuk, and Yanti (2016), who stated that inflation affects customer interest in Retail Sukuk 004 series. Thus, the results of this study reject $\mathrm{H}_{0}$, which states that inflation does not significantly affect the volume of Retail Sukuk SR-007 issuance.

Second, the exchange rate has significant long- and short-term effects on the volume of Retail Sukuk SR-007 issuance. The statement pays attention to the VECM test results between the t-statistic values with t-tables in the long run at $6.18676>1.69552$ and in the short-term at 3.46528>1.69552. Exposure to the exchange rate increases the risk for sovereign Sukuk issuers, especially those denominated in non-domestic currencies. For this reason, the government needs to carefully consider all economic policies that are put in place and have an impact on the exchange rate because capital market products will be significantly affected in the long run. The results of this study support Juaris et al. (2018), that the exchange rate has a significant effect on the issuance of Government Islamic Securities (SBSN), and Arshad, Muda, \& Osman (2018); Suriani, Majid, Masbar, \& Wahid (2018), that the Sukuk market is influenced by exchange rates and the exchange rate has a significant long-term effect on bond yields. Thus, the results of this study reject $\mathrm{H}_{0}$, which states that the exchange rate has no significant effect on the volume of Retail Sukuk SR-007 issuance.

The price of Sukuk has a long-term significant effect on the volume of Retail Sukuk SR-007 issuance. The influence is seen from the results of the VECM test between the t-statistics and t-table values in the long run of $2.33066>$ 1.69552. The results of this study support Aloui, Hammoudeh, \& Ben (2015), who stated that the GCC Sukuk price index has a significant impact on the probability of cross-regime transmission. Furthermore, the results of Sadeghi's (2011) study said that the investor's reaction to shares in accordance with Sharia is positive, which is reflected in the increase in stock prices and research. Wafa (2010) also stated that state Retail Sukuk prices have a significant influence on the level of demand for state Retail Sukuk-1. Thus, the results of this study reject $\mathrm{H}_{0}$, which states that the price of Sukuk has no significant effect on the volume of Retail Sukuk SR-007 issuance. 
Fourth, the yield does not affect the volume of Retail Sukuk SR-007 issuance in the long- or short-term, because the results of the VECM test between the t-statistic value with the long-term t-table is $-5.2568<1.69552$ and in the short-term at $-2.1340<1.69552$. The hypothesis is in accordance with the results of research conducted by Marimin et al. (2016), which states that there is no significant difference between the performance of retail bonds and Retail Sukuk if measured from the yield of each bond. Thus, the results of this study affirm $\mathrm{H}_{0}$, which states that the yield does not significantly affect the volume of Retail Sukuk SR-007 issuance.

\section{Conclusions and Suggestions}

This study aimed to determine the effects of inflation, exchange rates, Sukuk prices and yields on the volume of Retail Sukuk SR-007 issuance. Based on data that was processed using the VECM econometric EViews 9 method, it can be concluded that, long-term, the inflation and price variables significantly influence the Retail Sukuk SR-007 issuance volume; only the yield variable does not affect both the long- and short-term. In addition, only the exchange rate variable has a significant effect on the volume of Retail Sukuk SR-007 issuance in the long- and short-term.

These empirical findings contribute to the Indonesian government in increasing the volume of retail Sukuk issuance through pricing and yields of Sukuk as well as appropriate macroeconomic policies. Indonesia's inflation stability and exchange rate are important as economic policies in promoting internationally traded Sukuk. This study only explores the variables inherent in Sukuk, namely prices and yields as well as macroeconomic variables of inflation and the exchange rate of the Indonesian Rupiah against the US dollar. Further studies can consider variables about the importance of price levels, Sukuk results and macroeconomic policies in promoting the global Sukuk market.

\section{Acknowledgement}

This research is an outcome of Internal Research funded by Mercu Buana University Jakarta. Therefore, we would like to thank the Dean of the Faculty of Economics and Business, Chair of Accounting Program, Head of Research Centre and Director of Research \& Technology, Mercu Buana University, Jakarta.

\section{References}

Abad-Romero, P., \& Robles-Fernandez, M. D. (2006). Risk and return around bond rating changes: New evidence from the Spanish stock market. Journal of Business Finance \& Accounting, 33(5-6), 885-908.

Abaffy, J., Bertocchi, M., Dupačová, J., Moriggia, V., \& Consigli, G. (2007). Pricing nondiversifiable credit risk in the corporate Eurobond market. Journal of Banking \& Finance, 31(8), 2233-2263.

Abidin, S., Suhadak, \& Hidayat, R. R. (2016). Pengaruh Faktor-faktor Teknikal Terhadap Harga Saham. Jurnal Administrasi Bisnis, 37(1), 1-7.

Adam, N. J., \& Thomas, A. S. (2004). Islamic Bonds: Your guide to issuing, structuring and investing in Sukuk. Euromoney Books.

Agung, I. G. N. (2011). Time series data analysis using EViews. John Wiley \& Sons.

Ahmad, N., Hashim, N., \& Johari, F. (2015). Measuring the Size of Output Gap in Sukuk Issuing OIC Member Countries. Mediterranean Journal of Social Sciences, 6(2 S5), 249.

Ahmad, W., \& Radzi, R. M. (2011). Sustainability of sukuk and conventional bond during financial crisis: Malaysia's capital market. Global Economy and Finance Journal, 4(2), 33-45.

Ajija, S. R., Wulansari, D. W., Setianto, R. H., \& Primanti, M. R. (2011). Cara cerdas menguasai EViews. Penerbit Salemba Empat.

Alagidede, P., \& Ibrahim, M. (2017). On the causes and effects of exchange rate volatility on economic growth: Evidence from Ghana. Journal of African Business, 18(2), 169-193.

Aloui, C., Hammoudeh, S., \& Ben, H. (2015). Paci fi c-Basin Finance Journal Price discovery and regime shift behavior in the relationship between sharia stocks and sukuk: A two-state Markov switching analysis. Pacific-Basin Finance Journal, 34, 121-135. https://doi.org/10.1016/j.pacfin.2015.06.004

Apriliani, N., Azib, \& Senjiat, I. H. (2017). Analisis Pengaruh Inflasi dan PDB Perkapita Terhadap Tingkat Permintaan Sukuk Ritel di Indonesia Periode 2010 - 2017 Analysis of Effect of Inflation and GDP Perkapita to Retail Level Demand in Indonesia rangka mempersiapkan kebutuhannya di masa depan. Me, 935-944.

Ariefianto, M. D. (2012). Ekonometrika: Esensi dan Aplikasi dengan Menggunakan EViews. Jakarta: Erlangga.

Ariff, M., Chazi, A., Safari, M., \& Zarei, A. (2017). Significant Difference in the Yields of Sukuk Bonds versus Conventional Bonds. Journal of Emerging Market Finance, 16(2), 115-135. 
Ariff, M., Iqbal, M., \& Mohamad, S. (2012). The Islamic debt market for sukuk securities: The theory and practice of profit sharing investment. Edward Elgar Publishing.

Ariff, M., \& Safari, M. (2012). Are Sukuk the Same as Conventional Bonds?. Afro Eurasian Studies, 1(1), 1-31.

Arshad, H., Muda, R., \& Osman, I. (2018). Impact of exchange rate and oil price on the yield of sovereign bond and sukuk : Evidence from Malaysian capital market. Journal of Emerging Economies and Islamic Research, 5(July 2013), 27-41.

Bank Indonesia. (2018). Pengenalan Inflasi.

Bank, W. (2008). World Bank annual report 2008. World Bank, Washington.

Cheung, Y. L., Cheung, Y. W., He, A. W. W., \& Wan, A. T. K. (2010). A trading strategy based on Callable Bull/Bear Contracts. Pacific Basin Finance Journal, 18(2), 186-198. https://doi.org/10.1016/j.pacfin.2009.11.002

De Grauwe, P., \& Grimaldi, M. (2018). The exchange rate in a behavioral finance framework. Princeton University Press.

Direktorat Jenderal Pengelolaan Pembiayaan dan Risiko Kementerian Keuangan. (2018). Development of Sukuk Negara ( Success Story of Indonesia Sovereign Sukuk ).

Direktur Jenderal Pengelolaan Utang. (2009). Hasil Penerbitan Sukuk Negara Ritel Seri SR-001. Retrieved July 29, 2019, from https://www.antaranews.com/berita/133717/hasil-penerbitan-sukuk-negara-ritel-seri-sr-001

Fahmi, I. (2012). Pengantar Pasar Modal. Bandung: Alfabeta.

Fathurahman, H., \& Fitriati, R. (2013). Comparative Analysis of Return on Sukuk and Conventional Bonds. American Journal of Economics, 3(3), 159-163. https://doi.org/10.5923/j.economics.20130303.05

Friedman, M. (2017). Price theory. Routledge.

Galí, J., J. (2015). Monetary policy, inflation, and the business cycle: an introduction to the new Keynesian framework and its applications. United Kingdom: Princeton University Press.

Hansen, B. (2016). A Study in the Theory of Inflation. Routledge.

Hartono, J. (2016). Teori Portofolio dan Analisis Investasi (10th ed.). Yogyakarta: BPFE.

Hildenbrand, W. (2014). Market demand: Theory and empirical evidence (Vol. 215). Princeton University Press.

Hill, R. C., Griffiths, W. E., \& Lim, G. C. (2018). Principles of econometrics. John Wiley \& Sons.

Hox, J. J., Moerbeek, M., \& de Schoot, R. (2017). Multilevel analysis: Techniques and applications. Routledge.

Huda, N., \& Heykal, M. (2010). Lembaga Keuangan Syariah. In Tinjauan Teoretis dan Praktisi (Pertama). Jakarta: Kencana.

Huda, N., \& Heykal, M. (2013). Lembaga Keuangan Islam: Tinjauan Teoritis Dan Praktis. Jakarta: Kencana.

Jorion, P., \& Zhang, G. (2007). Information effects of bond rating changes: The role of the rating prior to the announcement. Journal of Fixed Income, Spring.

Juaris, Masbar, R., \& Seftarita, C. (2018). Analysis of The Effect of Monetary Policy on Government Sharia Securities (SBSN) in Indonesia, 2(2), 109-122.

Kamarudin, M. F., Kamaluddin, N., Manan, S. K. A., \& Ghani, G. M. (2014). Defaulters Profile in Malaysia Sukuk Market. Procedia - Social and Behavioral Sciences, 145, 277-285. https://doi.org/10.1016/j.sbspro.2014.06.035

Karpoff, J. M. (1986). A theory of trading volume. The Journal of Finance, 41(5), 1069-1087.

Kementerian Keuangan. (2018). \#SukukRitel010 Investasi Rakyat Penuh Manfaat. Jakarta.

Keynes, J. M. (2018). The general theory of employment, interest, and money. Springer.

Khatimah, H. (2017). Sukuk dan Kontribusinya Dalam Pembiayaan Pembangunan. Optimal, 11(1), 83-103.

Kuncoro, M. (2013). Mudah memahami dan menganalisis indikator ekonomi. Yogyakarta: UPP STIM YKPN.

Maiti, M. (2017). Book Review: Shankar Kumar Bhaumik, Principles of Econometrics: A Modern Approach Using EViews. SAGE Publications Sage India: New Delhi, India.

Malkiel, B. G. (2015). Term structure of interest rates: expectations and behavior patterns. Princeton University 
Press.

Manab, A., \& Sujianto, A. E. (2016). Pengaruh Stabilitas Ekonomi Makro Terhadap Penerbitan Sukuk Negara Di Indonesia, Malaysia dan Brunei Darussalam. Tulungagung: Cahaya Abadi.

Mankiw, N. G., Quah, E., \& Wilson, P. (2014). Pengantar Ekonomi Makro (Edisi Asia). Jakarta: Salemba Empat.

Marimin, A., Mustofa, U. A., \& Anik. (2016). Perbandingan Kinerja Obligasi Ritel Indonesia Dengan Sukuk Ritel Indonesia Periode Tahun 2011-2015. Jurnal Ilmiah Ekonomi Islam, 02(01), 43-52.

Melzatia, S., Doktoralina, C. M., \& Mahroji. (2018). Yield Sukuk: Maturity, Rating and Value of Emission. Research Journal of Finance and Accounting, 9(12), 106-112. Retrieved from http://iiste.org/Journals/index.php/RJFA/article/view/42964

Naifar, N. (2016). Modeling dependence structure between stock market volatility and sukuk yields: A nonlinear study in the case of Saudi Arabia. Borsa Istanbul Review, 16(3), 157-166. https://doi.org/10.1016/j.bir.2016.01.005

Noor, F. H. (2009). Investasi, Pengelolaan Keuangan Bisnis dan Pengembangan Ekonomi Masyarakat. Jakarta: PT Indeks.

Nurhayati, S., \& Wasilah. (2014). Akuntasi Syariah di Indonesia (4th ed.). Jakarta: Salemba Empat.

Oikawa, K., \& Ueda, K. (2018). The optimal inflation rate under Schumpeterian growth. Journal of Monetary Economics, 100, 114-125.

Otoritas Jasa Keuangan. (2018). Snapshot Perbankan Syariah Indonesia Juni 2018. Jakarta.

Ouliaris, S., Pagan, A., \& Restrepo, J. (2016). Quantitative Macroeconomic Modeling with Structural Vector Autoregressions-An EViews Implementation. Washington DC: IMF Institute for Capacity Development.

Pew Research. (2015). The Future of World Religions: Population Growth Projections, 2010-2050. Washington DC.

Putong, I. (2013). Economics Pengantar Mikro dan Makro (Edisi 5). Jakarta: Mitra Wacana Media.

Rahardjo, S. (2003). Panduan investasi obligasi. Jakarta: Gramedia Pustaka Utama.

Rahman, F., Paminto, A., \& Nardi, M. (2016). Pengaruh Harga Sukuk Negara Ritel Seri SR-005, Tingkat Inflasi dan BI RATE Terhadap Tingkat Permintaan Sukuk Negara Ritel Seri SR-005. Jurnal Manajemen, 8(1), 19-29.

Rahman, M. P., Duasa, J., Kassim, S., \& Zainudin, W. R. A. (2017). Sovereign Sukuk Pricing Analysis : Do Macroeconomic Variables Matter?. International Journal of Economics, Management and Accounting, 3(3), 513-528.

Sadeghi, M. (2015). Is Shariah-Compliant Investment Universally Sustainable? A Comparative Study. In Developing Inclusive and Sustainable Economic and Financial Systems (pp. 81-91). Natacha Fares.

Said, A., \& Grassa, R. (2013). The determinants of sukuk market development: does macroeconomic factors influence the construction of certain structure of sukuk?

Sholihin, A. I. (2010). Buku Pintar Ekonomi Syariah. PT Gramedia Pustaka Utama.

Sitorus, T. (2015). Pasar Obligasi Indonesia Teori dan Praktik. Jakarta: PT RajaGrafindo Persada.

Soekapdjo, S., Nugroho, L., Badawi, A., \& Utami, W. (2018). Bad debt issues in Islamic bank: macro and micro influencing (Indonesia cases).

Spence, M. (1973). Job Market Signaling. The Quarterly Journal of Economics, 87(3), 355. https://doi.org/10.2307/1882010

Suharto, F. T. (2015). Lebih Mudah dan Untung Berdagang Emas Ketimbang Main Forex. Jakarta: Kompas Gramedia.

Sukirno, S. (2012). Mikro Ekonomi Teori Pengantar. Depok: PT RajaGrafindo Persada.

Sukirno, S. (2015). Makroekonomi Teori Pengantar (3rd ed.). Jakarta: Rajawali Pers.

Sumaidi, P. (2018). Seminar KNKS: Keuangan dan Ekonomi Syariah Indonesia. Jakarta.

Suriani, Majid, M. S. A., Masbar, R., \& Wahid, N. A. (2018). Macroeconomic Determinants of the Capital Market in Indonesia: A Comparative Analysis between Sukuk and Bonds Markets. International Journal of Academic Research in Economics and Management Sciences, 7(2), 1-17. 
Thierry, B., Jun, Z., Eric, D. D., Yannick, G. Z. S., \& Landry, K. Y. S. (2016, October). Causality Relationship between Bank Credit and Economic Growth: Evidence from a Time Series Analysis on a Vector Error Correction Model in Cameroon. Procedia - Social and Behavioral Sciences, 235, 664-671. https://doi.org/10.1016/j.sbspro.2016.11.061

Tim Studi Minat Emiten di Pasar Modal. (2009). Studi Faktor-Faktor Yang Mempengaruhi Minat Emiten dalam Menerbitkan Sukuk di Pasar Modal. Jakarta.

Wafa, M. A. K. (2010). Analisa faktor-faktor yang mempengaruhi tingkat permintaan sukuk ritel-i (Periode Maret 2009-Juni 2010). La_Riba, 4(2), 161-178.

Wati, L. N. (2018). Metodologi Penelitian Terapan. Bekasi: CV. Pustaka Amri.

Widarjono, A. (2013). Ekonometrika Pengantar dan Aplikasinya Disertai Panduan EViews (4th ed.). Yogyakarta: UPP STIM YKPN.

Widyanto, H. (2018). Analisis Faktor Penyebab Gagal Bayar Obligasi Syariah Sukuk Ijarah Pt Berlian Laju Tanker. Majalah Ilmiah Bahari Jogja, 16(1), 65-88.

Yanti, S. D. (2016). Pengaruh Tingkat Inflasi terhadap Minat Nasabah pada Produk Sukuk Ritel Seri 004 di Bank Syariah Mandiri Kantor Cabang Ahmad. Prosiding Keuangan Dan Perbankan Syariah, 2(1), 495-502.

Zulkhibri, M. (2015). A synthesis of theoretical and empirical research on sukuk. Borsa Istanbul Review, 15(4), $237-248$.

\section{Copyrights}

Copyright for this article is retained by the author(s), with first publication rights granted to the journal.

This is an open-access article distributed under the terms and conditions of the Creative Commons Attribution license (http://creativecommons.org/licenses/by/4.0/). 